\title{
BIOPHARMACEUTICAL ASPECTS OF TECHNOLOGY OF SOFT MEDICINAL FORMS
}

\section{Tarasenko V. O., Pidlisniy O. V.}

\section{INTRODUCTION}

Creating new drugs, improving their effectiveness is impossible without a comprehensive study of the role of factors that affect the degree of release of drugs from the dosage form, the speed and completeness of their absorption, local or direct effects on tissues, organs, etc. that is, without their biopharmaceutical research.

Pharmaceutical factors (route of drug administration, type of dosage form, physicochemical state of active pharmaceutical ingredients (API), excipients, manufacturing technology) determine the effectiveness and safety of the drug and are the basis for pharmaceutical development ${ }^{1}$.

The right choice of dosage form. It is known that the drug consists not only of the active substance - the main carrier of therapeutic effect, but also of a combination of chemical compounds, both organic and inorganic in nature (solvents, preservatives, fillers, etc.). Therefore, in the successful biography of a medicinal product, the optimal dosage form plays a crucial role.

The composition and design of the dosage form is a compromise between the stringent requirements for the dosage form and the level of development of modern technology. The requirements for the dosage form depend on the type of disease, the localization of the focus of the pathological process, the properties of the active pharmaceutical ingredients, the route of administration of the drug, the presence of additional requirements ${ }^{2}$.

${ }^{1}$ Sheskey P.J., Cook W.G., Cable C. G. Handbook of pharmaceutical excipients. London: APhA/Pharmaceutical Press, 2017. ISBN 9780857112712. 0857112716.

2 11. Abrantes C.G., Duarte D., Reis C.P. An overview of pharmaceutical excipients: safe or not safe. Journal Pharmaceutical Science. 2016. № 105(7). P. 2019-2026. DOI 10.1016/j.xphs.2016.03.019.

Chan B.A., Sunting X.Li.A., Simpson J.M., Sternhagen G.L., Yu T., Darvish O.A., Naisheng J., Donghui Z. Polypeptid polymers: synthesis, characterization, and properties. Biopolymers. 2017. DOI 10.1002/bip.23070.

Chauhan N.P.S., Pathak A.K., Bhanat K. Encyclopedia of biomedical polymers and polymeric biomaterials. Taylor \& Francis, New York. 2016. ISBN-13: 978-1439898796. ISBN-10: 1439898790. 
To date, the nomenclature of dosage forms has not expanded particularly, but varieties with a modified release of active pharmaceutical ingredients (prolonged or accelerated) have appeared. Research in the field of creating dosage forms with prescribed pharmacokinetic characteristics has led to the invention of many different types of micro- and nanocarriers of active substances - drug delivery systems. An analysis of the types and structures of nanocarriers, as well as the classification of auxiliary substances for delivery systems according to their functional characteristics, are already given in the works of scientists ${ }^{3}$.

Thus, the biopharmaceutical development of the concept of dosage forms currently provides the opportunity for the creation of medicines with high characteristics of efficacy and safety.

\section{Biopharmaceutical factors that affect the bioavailability of drugs}

One of the factors of the bioavailability of a medicinal product is the physical condition of the medicinal substance (degree of crushing, physicochemical status, etc.), which has a significant impact on the processes of absorption, distribution and release from the body, that is on the therapeutic efficacy and bioavailability of the drug ${ }^{4}$.

Physico-chemical properties (state) of active pharmaceutical ingredients. This applies to crushing, polymorphism, crystallinity, and optical properties of active substances. Chemical modification of a substance significantly affects the kinetics of absorption and release from the body ${ }^{5}$. To change the properties of active substances, general pharmaceutical methods are used: the formation of salts, cocrystals, hydrates, solvates, polymorphic modifications ${ }^{6}$.

${ }^{3}$ Debjit B., Harish G., B. Pragati K.S., Duraivel K.P., Sampath K. Recept advances in novel topical drug delivery system. The Pharma Innovation. 2012. № 1 (9). P. 12-31. ISSN: 2277-7695.

Farooq U., Rishabh M., Bansal V., Pragati K.S. Characterization of some polymers as pharmaceutical excipient. Advances in Biological Research. 2014. № 8 (3). P. 123-126. DOI 10.5829/idosi. abr.2014.8.3.83200.

4 Kadajji V.G., Betageri G.V. Water soluble polymers for pharmaceutical Applications. Polymers. 2011. № 3(4). P. 1972-2009. DOI 10.3390/ polym3041972.

Kiamahalleh M.V., Mellati A., Madani S.A., Pendleton Ph., Zhang Hu, Hadi Madani, S.H. Smart carriers for controlled drug delivery: thermosensitive polymers embedded in ordered mesoporous carbon. Journal Pharmaceutical Science. 2017. № 106(6). DOI 10.1016/j.xphs.2017.02.010.

${ }^{5}$ Sheskey P.J., Cook W.G., Cable C. G. Handbook of pharmaceutical excipients. London : APhA/Pharmaceutical Press, 2017. ISBN 9780857112712.0857112716.

6 Merkle H.P. Drug delivery's quest for polymers: where are the frontiers? European Journal Pharmaceutical Biopharmaceutic. 2015. №97. P. 293-303. DOI 10.1016/j.ejpb.2015.04.038. 
Recently, the substances of many active pharmaceutical ingredients have been marketed in the form of solid dispersions (dispersion of a substance in a water-soluble carrier), in which polyethylene glycol, polyvinylpyrrolidone (PVP), hydroxypropyl methylcellulose, polyvinyl alcohol, etc. are used as carriers ${ }^{7}$.

The degree of crushing the drug affects the pharmacokinetics of the drug, regardless of the route of its introduction into the body in the form of various dosage forms. The bioavailability of the same drug varies depending on the degree of crushing of the drug. For example, levomycetin, crushed to a microcrystalline state, is released more quickly from the base and is absorbed in large quantities through the skin. Thus, if the growth inhibition zone of the test cultures when using levomycetin in the microcrystalline state is from 33.4 (emulsion basis) to $38.1 \mathrm{~mm}$ (methylcellulose-gel basis), then with particle sizes of $0.16 \mathrm{~mm}$, the growth inhibition zone decreases from 27.4 to 28.7 respectively $^{8}$. That is, with increasing the dispersion of the particles increases the ability of the drug to diffuse from the carrier, which leads to an increase in its concentration on the border of ointment - skin. Therefore, the use of micronized substances can reduce their dosage with the same therapeutic effect ${ }^{9}$.

The solubility of the drug also has an effect on the bioavailability of the drug. For example, it is proved that lidocaine introduced into the ointment as a base has a longer duration than lidocaine hydrochloride ${ }^{10}$. That is, with

7 Давтян Л., Дроздов О., Гладышев В., Пухальская И. Фармацевтическая технология экстемпоральных лекарственных средств. 2018. 700 с.

Chauhan N.P.S., Pathak A.K., Bhanat K. Encyclopedia of biomedical polymers and polymeric biomaterials. Taylor \& Francis, New York. 2016. ISBN-13: 978-1439898796. ISBN-10: 1439898790.

Gullapalli R.P. Soft gelatin capsules (softgels). Journal Pharmaceutical Science. 2010. № 99(10). p. 47-48. DOI 10.1002/jps.22151.

${ }^{8}$ Haag R., Kratz F. Polymer therapeutics: concepts and applications. 2006. № 45(8). P. 1198-215. DOI 10.1002/anie.200502113.

Islam M.T., Rodríguez-Hornedo N.P., Ciotti S.E. Rheological characterization of topical carbomer gels neutralized to different $\mathrm{pH}$. Journal Pharmaceutical Research. 2014. № 7(21), p. 1192-1199. DOI 21:1192-1199.

9 Kadajji V.G., Betageri G.V. Water soluble polymers for pharmaceutical Applications. Polymers. 2011. № 3(4). p. 1972-2009. DOI 10.3390/ polym3041972.

Kiamahalleh M.V., Mellati A., Madani S.A., Pendleton Ph., Zhang Hu, Hadi Madani, S.H. Smart carriers for controlled drug delivery: thermosensitive polymers embedded in ordered mesoporous carbon. Journal Pharmaceutical Science. 2017. № 106(6). DOI 10.1016/j.xphs.2017.02.010.

10 Давтян Л.Л. Технологічний спосіб введення діючих речовин до основи препарату. Військова медиична Украӥни. 2012. № 12(4). С. 61-63. 
increasing solubility of the drug substance increases the release of substances from the base. To achieve a certain therapeutic effect, they increase the solubility of many drugs by using absorption "activators": dimethylsulfoxide, polyethylene oxide, surfactants, etc. The latter increase the thermodynamic activity of the drug substance in the stratum corneum and increase the permeability of the drug substance through the skin ${ }^{11}$.

Excipients, their nature and quantity affect the therapeutic activity of active pharmaceutical ingredients and the physico-chemical characteristics of the dosage form during their manufacture and storage ${ }^{12}$.

Excipients are administered to provide the soft dosage form with the necessary pharmacological characteristics. For example, in ointments, gels, films, etc. excipients make up more than $90 \%$ of the composition and therefore, they significantly alter the pharmacokinetics of the drug.

The use of any excipient in each case requires specific research to determine its impact on the technological process and bioavailability of the drug. Moreover, none of the pharmaceutical factors have as complex and significant effects on the active substances as the excipients. As a kind of carrier of pharmacologically active substances, the latter themselves have certain physicochemical properties. Therefore, in each case, the combination of excipients and drugs in the appropriate dosage form must be individual, taking into account the pharmacokinetics of the drug.

Thus, the experiment proved that the excipients change the completeness and speed of absorption of the drug ${ }^{13}$.

International pharmaceutical organizations (ICH, IPEC, FDA) have suggested that excipients, along with active pharmaceutical ingredients, be classified as "for pharmaceutical use", and their quality control should be carried out according to the relevant pharmacopoeial articles. Currently in the world in

\footnotetext{
Кузьмін Ю., Самсон А., Самсон М. Антибактеріальна терапія гнійних ран. Медична допомога. 2018. № 7(94). С. 13-18.

${ }^{11}$ Chauhan N.P.S., Pathak A.K., Bhanat K. Encyclopedia of biomedical polymers and polymeric biomaterials. Taylor \& Francis, New York. 2016. ISBN-13: 978-1439898796. ISBN-10: 1439898790.

Farooq U., Rishabh M., Bansal V., Pragati K.S. Characterization of some polymers as pharmaceutical excipient. Advances in Biological Research. 2014. № 8 (3). P. 123-126. DOI 10.5829/idosi. abr.2014.8.3.83200.

12 Janis J. E., Harrison B. Wound healing: part I. Basic science. Plastic and Reconstructuctive Surgery. 2016. № 138(3). P. 9-17. DOI 10.1097/PRS.0000000000002773.

Maitz M.F. Applications of synthetic polymers in clinical medicine. Biosurface and Biotribology. 2015. № 1(3). DOI 10.1016/j.bsbt.2015.08.002.

13 Merkle H.P. Drug delivery's quest for polymers: where are the frontiers? European Journal Pharmaceutical Biopharmaceutic. 2015. №97. P. 293-303. DOI 10.1016/j.ejpb.2015.04.038.
} 
the manufacture of medicines use more than 500 kinds of excipients. Most of them are included in national and international pharmacopoeias (Eur.Ph., Br.Ph., USP, JP) or national directories (Inactive Ingredients Guides of the FDA, Handbook of Pharmaceutical Excipients and others) ${ }^{14}$.

The range of excipients in the technology of soft medicines is particularly wide, where their importance and role as bases are very important and diverse ${ }^{15}$.

Among the biopharmaceutical factors that have a significant impact on the bioavailability of medicines, particular attention is paid to the basis. In the treatment of dermatological diseases, the role of the base is significant. It affects the condition, properties, and course of the pathological process of the particular site on which the drug is applied ${ }^{16}$. $\mathrm{In}^{17}$ it is shown that the bases in soft dosage form by their ability to provide the most intensive selection and resorption of medicinal substance can be arranged in the following order: gels of hydrophilic substances > emulsion bases type oil / warter > emulsion bases type warter / oil > hydrophobic bases.

In surgery for the treatment of wounds, preference should be given to hydrophilic bases, since to achieve optimal therapeutic effect in pathological lesions requires complete mixing of the drug (and therefore the basics) with the excretion of the affected area ${ }^{18}$.

14 Державна Фармакопея України / Державне підприємство “Український науковий фармакопейний центр якості лікарських засобів”. 2-е вид. Доповнення 3. Харків : Державне підприємство "Український науковий фармакопейний центр якості лікарських засобів”. 2018. 416 с. ISBN 978-966-97390-4-9.

Стефанов О.В.(ред.), Доклінічні дослідження лікарських засобів. 2001. 535 с.

Sheskey P.J., Cook W.G., Cable C. G. Handbook of pharmaceutical excipients. London : APhA / Pharmaceutical Press, 2017. ISBN 9780857112712. 0857112716.

Swarbrick J. Encyclopedia of pharmaceutical science and technology. Fourth Edition, Six Volume Set Dasel Marcel Dekker, New York. 2013. ISBN 9781841848198-CAT\# H100233.

${ }^{15}$ Chauhan N.P.S., Pathak A.K., Bhanat K. Encyclopedia of biomedical polymers and polymeric biomaterials. Taylor \& Francis, New York. 2016. ISBN-13: 978-1439898796. ISBN-10: 1439898790.

Farooq U., Rishabh M., Bansal V., Pragati K.S. Characterization of some polymers as pharmaceutical excipient. Advances in Biological Research. 2014. № 8 (3). P. 123-126. DOI 10.5829/idosi.abr.2014.8.3.83200.

${ }^{16}$ Healy B.M., Freedman A.M. ABC of wound healing Infections. British Medical Journal. 2010. № 332. P. 838-841. DOI 10.1136/bmj.332.7545.838.

17 Давтян Л., Власенко І. Мікробіологічний скринінг - основа для створення препаратів для лікування тропічних виразок. Pещепт. 2017. № 20(1). С. 69-78.

18 Atiyeh B.S., Dibo S.A., Hayek S.N. Wound cleansing, topical antiseptics and wound healing. International Wound Journal. 2009. № 6(6). P. 420-430. DOI 10.1111/j.1742-481X.2009. 00639.x. 
There are several classifications of the fundamentals of soft dosage forms, the construction principle of which is important for the method of their manufacture: this is the degree of affinity of the properties of the active pharmaceutical ingredients and bases, the possibility of dissolving the active pharmaceutical ingredients in the base. In accordance with this principle, all ointment bases are divided into three groups: lipophilic, hydrophilic, lipophilic-hydrophilic ${ }^{19}$.

Lipophilic (hydrophobic) bases include: fat bases (animal and vegetable fats - pork fat, goose fat, beef tallow, almond oil, apricot, peach, sunflower, olive, etc.), hydrogenated fats (products of industrial processing of fats and vegetable oils); hydrocarbon bases (petrolatum, paraffin, petrolatum, petroleum jelly, naphthalan oil, ozokerite, ceresin); silicone (polydimethylsilicone liquid, polydiethylsilicone liquid, polymethylphenylsilicone liquid, aerosil, esilon $-4,5$, esilon - aerosil base $)^{20}$.

A common disadvantage of fat and hydrocarbon bases is easy rancidity in air, especially in the presence of water. The pharmacological indifference of fats is directly dependent on their freshness, rancid fats irritate the skin and mucous membranes. In addition, fatty bases have an unpleasant odor and dirty properties, reduce the release rate of active pharmaceutical ingredients, undergo microbial contamination, are scarce foods and are unsuitable for the preparation of ointments containing alkalis, oxides and salts of heavy metals ${ }^{21}$.

Hydrophobic bases are guaranteed to provide the form of a soft drug, but they minimize the dynamic processes associated with the diffusion and release of active pharmaceutical ingredients, as a result of which drugs are

Cardinal M.M., Eisenbud D.E., Armstrong D.G. Serial surgical debridement: a retrospective study on clinical outcomes in chronic lower extremity wounds. Wound Repair and Regeneration. 2009. № 17(3). P. 306-311. DOI 10.1111/j.1524475X.2009.00485. x.

Dohmen P.M. Antibiotic resistance in common pathogens reinforces the need to minimize surgical site infections. Journal of Hospital Infection. 2008. № 70(2). P. 15-20. DOI 10.1016/S0195-6701(08)60019-5.

${ }^{19}$ Sheskey P.J., Cook W.G., Cable C. G. Handbook of pharmaceutical excipients. London: APhA/Pharmaceutical Press, 2017. ISBN 9780857112712. 0857112716.

Swarbrick J. Encyclopedia of pharmaceutical science and technology. Fourth Edition, Six Volume Set Dasel Marcel Dekker, New York. 2013. ISBN 9781841848198-CAT\# H100233.

${ }^{20}$ Maitz M.F. Applications of synthetic polymers in clinical medicine. Biosurface and Biotribology. 2015. № 1(3). DOI 10.1016/j.bsbt.2015.08.002.

${ }^{21}$ Dohmen P.M. Antibiotic resistanse in common pathogens reinforces the need to minimize surgical site infections. Journal of Hospital Infection. 2008. № 70(2). P. 15-20. DOI 10.1016/S0195-6701(08)60019-5. 
ineffective $^{22}$. When using hydrophobic bases, drug developers should increase the effectiveness of drugs by increasing the concentration of active pharmaceutical ingredients. In addition, such bases interfere with the normal functioning of the skin, and in some cases, the use of ointments on petrolatum bases is strictly contraindicated. The hydrophilic bases include: gels of high molecular weight carbohydrates and proteins (soap-glycerin, starch-glycerin, gelatin-glycerin, methyl cellulose, sodium carboxymethyl cellulose; synthetic (polyethylene oxide bases, polyethylene gels; c) inorganic gels. Lipophilic-hydrophilic bases: absorption (alloys of lipophilic bases with emulsifiers (lanolin anhydrous, spermaceti, wax); emulsion (oil / warter, warter / oil type). However, this classification does not fully reflect modern ideas about excipients, since the same compound can be used in different dosage forms ${ }^{23}$.

Another classification divides auxiliary substances, depending on the effect on the physicochemical characteristics and pharmacokinetics of the dosage form, into the following groups: formative, stabilizing, prolonging, solubilizing, corrective ${ }^{24}$.

But some authors exclude the group of forming substances, since shaping, as a rule, is the result of the ${ }^{25}$ ombined action of several auxiliary substances with different technological functions ${ }^{26}$.

Polymers are important for creating new soft dosage forms. Polymers are used as fat-free bases and for stabilization of emulsions, suspensions. The main polymers intended for this are polyethylene oxide (PEO), polyvinyl alcohol,

${ }^{22}$ Debjit B., Harish G., B. Pragati K.S., Duraivel K.P., Sampath K. Recept advances in novel topical drug delivery system. The Pharma Innovation. 2012. № 1 (9). P. 12-31. ISSN: 2277-7695.

${ }^{23}$ Chauhan N.P.S., Pathak A.K., Bhanat K. Encyclopedia of biomedical polymers and polymeric biomaterials. Taylor \& Francis, New York. 2016. ISBN-13: 978-1439898796. ISBN-10: 1439898790.

Merkle H.P. Drug delivery's quest for polymers: where are the frontiers? European Journal Pharmaceutical Biopharmaceutic. 2015. № 97. P. 293-303. DOI 10.1016/j.ejpb.2015.04.038.

${ }^{24}$ Chan B.A., Sunting X.Li.A., Simpson J.M., Sternhagen G.L., Yu T., Darvish O.A., Naisheng J., Donghui Z. Polypeptid polymers: synthesis, characterization, and properties. Biopolymers. 2017. DOI 10.1002/bip.23070.

${ }^{25}$ Sheskey P.J., Cook W.G., Cable C. G. Handbook of pharmaceutical excipients. London : APhA/Pharmaceutical Press, 2017. ISBN 9780857112712.0857112716.

${ }^{26}$ Swarbrick J. Encyclopedia of pharmaceutical science and technology. Fourth Edition, Six Volume Set Dasel Marcel Dekker, New York. 2013. ISBN 9781841848198CAT\# H100233. 
polyvinylpyrrolidone ${ }^{27}$. Promising are polymer compounds, the molecules of which contain several types of monomer units or the so-called copolymers ${ }^{28}$.

For the creation of sustained release active pharmaceutical ingredient delivery systems, the most commonly used polymers are polylactic, polyglycolic acid, as well as lactic and glycolic acid-based polymers and copolymers ${ }^{29}$.

As a result of research in the field of prolongation polymers, a number of promising new polymers have been proposed that have high affinity for the biological tissues of living organisms and, in some cases, undergo biodegradation not to free acids, but to alcohols and other monomers less aggressive with respect to biological systems. Biodegradable polyakryl carbonates, such as polyethylene carbonate, polypropylene carbonate, copolymers of ethylene and propylene carbonates, are used as the basis for local anesthetics ${ }^{30}$.

Polyanhydrides have great potential as biocompatible carriers of active pharmaceutical ingredients. The biodegradation products of polyanhydrides are the corresponding dicarboxylic acids, which are involved in metabolic processes. As a result of the destruction of the modified polyanhydrides, modifier residues (for example, amino acids) are additionally formed, which are chosen so that they are absorbed by the body. In this regard, polyanhydrides are interesting esters that are capable of undergoing destruction with the formation of salicylic acid, which has anti-inflammatory properties ${ }^{31}$.

Of considerable interest are polymer complexes, in particular polyionic ones, which are formed upon mixing in a solution of oppositely charged polyelectrolytes. A directed change in the conditions for obtaining such complexes (type and concentration of polymers, the ratio of charged fragments of the polycation and polyanion, temperature, etc.) allows one to obtain nanoparticles of various types (nanoparticles, micelles, nanogels, hollow nanospheres) ${ }^{32}$. As an example, polyionic complexes based

${ }^{27}$ Haag R., Kratz F. Polymer therapeutics: concepts and applications. 2006. № 45(8). P. 1198-215. DOI 10.1002/anie.200502113.

28 Kadajji V.G., Betageri G.V. Water soluble polymers for pharmaceutical Applications. Polymers. 2011. № 3(4). P. 1972-2009. DOI 10.3390/ polym3041972.

${ }^{29}$ Sheskey P.J., Cook W.G., Cable C. G. Handbook of pharmaceutical excipients. London: APhA/Pharmaceutical Press, 2017. ISBN 9780857112712.0857112716.

${ }^{30}$ Swarbrick J. Encyclopedia of pharmaceutical science and technology. Fourth Edition. Six Volume Set Dasel Marcel Dekker, New York. 2013. ISBN 9781841848198CAT\# H100233.

31 Давтян Л., Дроздов О., Гладышев В., Пухальская И. Фармацевтическая технология экстемпоральных лекарственных средств. 2018. 700 с.

32 Hotz B.V., Visekruna A.A., Buhr H.J., Hotz H.G. Beyond epithelial to mesenchymal transition: a novel role for the transcription factor snail in inflammation and 
on poly- $\gamma$-glutamic acid and chitosan are used to produce nanoparticles, hydrogels, and films of biomedical application ${ }^{33}$.

For practical pharmacy, Ukrainian scientists provide generalized information on the properties of commonly used emulsifying substances on the basis of the International Pharmacopoeias, with which you can purposefully select excipients, taking into account the biomedical requirements for the drug being developed ${ }^{34}$.

As thickeners, structure-forming and emollients, polyethyleneglycol-400, emulsifier № 1, PEO, polyvinylpyrrolidone-3, castor oil, glycerin, methyl cellulose derivatives are used ${ }^{35}$.

Microcrystalline cellulose is widely used in modern pharmacy, given its ability to disperse under the influence of high shear stresses in water with the formation of stable gel-like dispersions ${ }^{36}$. High chemical purity and physiological inertness of cellulose in combination with chemical resistance, insolubility in water and organic solvents, lack of taste, smell, and color make it possible to use it as a filler, stabilizer, and emulsifier in the pharmaceutical and cosmetic industries ${ }^{37}$.

wound healing. World Journal of Gastrointestinal Surgery. 2010. № 14(2). P. 388-397. DOI 10.1007/s11605-009-1068-3.

Isaas V. L. B., Galdorfini Chiari-Andreo B., Marto J.M., Moraes J.D.D., Leone B.A., Correa M.A., Ribeiro H.M. Rheology as a tool to predict the release of alfa-lipoic acid from emulsions used for the prevention of skin aging. Hindawi Publishining International. 2015. P. 8-16. DOI 10.1155/2015/818656.

Lindley L.E., Stojadinovic O., Pastar I., Tomic-Canic M. Biology and biomarkers for wound healing. Plastic and Reconstructive Surgery. 2016. № 138(3). P. 18-28. DOI 10.1097/PRS.0000000000002682.

${ }^{33}$ Maisch T. Anti-microbial photodynamic therapy: useful in the future. Lasers in Medical Science. 2007. 22(2). P. 83-91. DOI 10.1007/s10103-006-0409-7.

${ }^{34}$ Sheskey P.J., Cook W.G., Cable C. G. Handbook of pharmaceutical excipients. London: APhA/Pharmaceutical Press, 2017. ISBN 9780857112712. 0857112716.

35 Swarbrick J. Encyclopedia of pharmaceutical science and technology. Fourth Edition. Six Volume Set Dasel Marcel Dekker, New York. 2013. ISBN 9781841848198 CAT\# H100233.

${ }^{36}$ Abrantes C.G., Duarte D., Reis C.P. An overview of pharmaceutical excipients: safe or not safe. Journal Pharmaceutical Science. 2016. № 105(7). P. 2019-2026. DOI 10.1016/j.xphs.2016.03.019.

Debjit B., Harish G., B. Pragati K.S., Duraivel K.P., Sampath K. Recept advances in novel topical drug delivery system. The Pharma Innovation. 2012. № 1 (9). P. 12-31. ISSN: 2277-7695.

${ }^{37}$ Chan B.A., Sunting X.Li.A., Simpson J.M., Sternhagen G.L., Yu.T., Darvish O.A., Naisheng J., Donghui Z. Polypeptid polymers: synthesis, characterization, and properties. Biopolymers. 2017. DOI 10.1002/bip.23070. 
Currently, an intensive search is underway for new excipients in order to increase the shelf life of the drugs. The addition of various stabilizing substances ensures high drug efficacy for a long time, which is not only of great medical, but also economic importance, as it allows to increase their shelf life $\mathrm{e}^{38}$.

The most promising in this regard is the creation of multicomponent compositions using polyethylene glycol, PVP, cellulose derivatives, collagen as the basic substances. Collagen can be obtained in the form of fibers, films, sponges, powder and gels of various viscosities. Unlike other base-forming and polymeric substances, it is water- and gas-permeable, has a high sorption ability with respect to biologically active substances, is indifferent, like a biopolymer, has a high affinity for the human body, is easily resorbed and utilized in $\mathrm{it}^{39}$.

Today, the industry produces not only a significant range, but also a line of one type of excipients whose brands differ in particle size, bulk density, flowability, which allows you to choose a product that provides the specified technological parameters of quality, while paying attention to the morphology of the particles and their sizes. Already in some countries, a classification of particles has been compiled, linking the shape and topography of their surface with technological characteristics ${ }^{40}$.

Hydrogels based on rare-crosslinked acrylic polymers are recognized as promising for the development of new foundations for soft medicine forms. When applied to the skin, such gels form the thinnest smooth films, providing a prolonged effect of the preparations, more fully and evenly release API, are well distributed over the mucous and skin surfaces, have a cooling effect, do not have toxicity and irritating effect. Applications of

Chauhan N.P.S., Pathak A.K., Bhanat K. Encyclopedia of biomedical polymers and polymeric biomaterials. Taylor \& Francis, New York. 2016. ISBN-13: 978-1439898796. ISBN-10: 1439898790.

${ }^{38}$ Sheskey P.J., Cook W.G., Cable C. G. Handbook of pharmaceutical excipients. London: APhA/Pharmaceutical Press, 2017. ISBN 9780857112712. 0857112716.

39 Swarbrick J. Encyclopedia of pharmaceutical science and technology. Fourth Edition, Six Volume Set Dasel Marcel Dekker, New York. 2013. ISBN 9781841848198CAT\# H100233.

${ }^{40}$ Кузьмін Ю., Самсон А., Самсон М. Антибактеріальна терапія гнійних ран. Медична допомога. 2018. № 7(94). С. 13-18.

Abrantes C.G., Duarte D., Reis C.P. An overview of pharmaceutical excipients: safe or not safe. Journal Pharmaceutical Science. 2016. № 105(7). P. 2019-2026. DOI 10.1016/j.xphs.2016.03.019.

Barajas-Nava L.A., López-Alcalde J., Roqué i Figuls M., Solà, I., Bonfill Cosp X. Antibiotic prophylaxis for preventing burn wound infection. Cochrane Database of Systematic Reviews. 2013. № 6. DOI 10.1002/14651858. CD008738. pub2. 
hydrogel-based preparations are aesthetic in appearance, do not spread, do not stain clothes, and are easily washed off with water ${ }^{41}$.

Poloxamer gels are used because of their unique properties, such as in situ thermosetting of gels. Poloxamers are well known as nonionic surfactants (surfactants), which form aqueous gels that undergo transformations from a state of low viscosity to a state of high viscosity as a result of temperature increase (thermal gelation) ${ }^{42}$. Modern high molecular weight compounds (Navy) (cremophor RH-40, CCMA, Lutrol F-68) contribute to the increased adsorption activity of drugs ${ }^{43}$.

The type of dosage form, the way it is introduced into the body are factors influencing the degree of bioavailability of the drug and provide optimal conditions for the release and absorption of the drug. Choosing a rational dosage form optimizes the pharmacokinetics of the drug.

The pharmacokinetics of the drug substance in the dosage form is significantly influenced by the technological process. The rational use of technological methods ensures a uniform distribution of substances in the base, their stability throughout the storage time, release of active substances from the base and optimal pharmacotherapeutic effect ${ }^{44}$.

Thus, the creation of a new drug presupposes the need for a scientifically sound approach to the full utilization of almost all pharmaceutical factors that significantly affect the bioavailability of a drug. However, the effect of each of these factors on the pharmacokinetics of the drug should not be considered unequivocally, as several factors can be combined at one time. Sometimes such a combination is used to produce a potentiating effect. Therefore, the optimization of the composition and technology of drugs with a guaranteed pharmacotherapeutic effect is possible after comprehensive biopharmaceutical research ${ }^{45}$.

${ }^{41}$ Sheskey P.J., Cook W.G., Cable C. G. Handbook of pharmaceutical excipients. London: APhA/Pharmaceutical Press, 2017. ISBN 9780857112712. 0857112716.

${ }^{42}$ Debjit B., Harish G., B. Pragati K.S., Duraivel K.P., Sampath K. Recept advances in novel topical drug delivery system. The Pharma Innovation. 2012. № 1 (9). P. 12-31. ISSN: 2277-7695.

${ }_{43}$ Swarbrick J. Encyclopedia of pharmaceutical science and technology. Fourth Edition, Six Volume Set Dasel Marcel Dekker, New York. 2013. ISBN 9781841848198CAT\# H100233.

44 Давтян Л.Л. Технологічний спосіб введення діючих речовин до основи препарату. Військова медицина України. 2012. № 12(4), с. 61-63.

Chauhan N.P.S., Pathak A.K., Bhanat K. Encyclopedia of biomedical polymers and polymeric biomaterials. Taylor \& Francis, New York. 2016. ISBN-13: 978-1439898796. ISBN-10: 1439898790.

45 Давтян Л., Дроздов О., Гладышев В., Пухальская И. Фармацевтическая технология экстемпоральных лекарственных средств. 2018. 700 с. 
Pharmaceutical technology. Increasing the solubility of active pharmaceutical ingredients in solvents implies a significant increase in their effectiveness. Therefore, an important issue of pharmaceutical technology is to increase the solubility of sparingly soluble active pharmaceutical ingredients in water and lipids, since their bioavailability largely depends on particle size and degree of coagulation. The smaller the radius of the particle, the lower the energy of adsorption, which expresses the strength of the fastening of the particles on the interfacial surface. Therefore, too small particles are not fixed on the surface. Therefore, too small particles are not fixed on the surface. It was experimentally shown that particles smaller than $100 \mathrm{~nm}$ in size are fixed on the oil surface only in aggregated form ${ }^{46}$. The relationship between particle aggregation and emulsion stability is explained by increased rheological characteristics of interfacial films ${ }^{47}$.

Particle sizes affect not only the transport function and specificity of the API, but also the rate of their release from the body, ceteris paribus ${ }^{48}$. It is also possible to increase the solubility of API by using cosolvents (benzyl benzoate, benzyl alcohol, propylene glycol (PG), PEO, etc.), hydrotropic agents (urea, sodium salicylate, etc.), as well as solubilization and complexation phenomena ${ }^{49}$.

Давтян Л., Власенко І. Мікробіологічний скринінг - основа для створення препаратів для лікування тропічних виразок. Рецепт. 2017. № 20(1). С. 69-78.

${ }_{46}$ Вікторов О. П., Кашуба О.В. Німесулід: оцінимо перспективи лікування [Німесулід: оцінка перспектив]. Мистецттво лікування. 2015. № 5. С. 20-22.

Руденко В.В., Власенко І.О., Ващук В.А. Вивчення осмотичної активності комбінації гідрофільних неводних розчинників для моделювання препарату, дослідження осмотичної активності комбінацій гідрофільних неводних розчинників для моделювання лікарського засобу для обробки в процесі лікування ран фази I. Фармацевтичний журнал. 2013. № 1. С. 46-49. ISSN 0367-3057.

${ }^{47}$ Puoci F., Piangiolino C., Givigliano F., Parisi O. I., Cassano R., Trombino S., Curcio M., Iemma F., Cirillo G., Spizzirri U. G., Restuccia D., Muzzalupo R., Picci, N. Ciprofloxacin-collagen conjugate in the wound healing treatment. Journal of Functional Biomaterials. 2012. № 3. P. 361-371. DOI 10.3390/ jfb3020361.

Sheskey P.J., Cook W.G., Cable C. G. Handbook of pharmaceutical excipients. London: APhA/Pharmaceutical Press, 2017. ISBN 9780857112712. 0857112716.

${ }^{48}$ Debjit B., Harish G., B. Pragati K.S., Duraivel K.P., Sampath K. Recept advances in novel topical drug delivery system. The Pharma Innovation. 2012. № 1 (9). P. 12-31. ISSN: 2277-7695.

Sheskey P.J., Cook W.G., Cable C. G. Handbook of pharmaceutical excipients. London: APhA/Pharmaceutical Press, 2017. ISBN 9780857112712.0857112716.

49 Swarbrick J. Encyclopedia of pharmaceutical science and technology. Fourth Edition, Six Volume Set Dasel Marcel Dekker, New York. 2013. ISBN 9781841848198CAT\# H100233. 
The most important problem in pharmaceutical technology is the stabilization of the drug. This is due to the fact that actively pharmaceutical ingredients under the influence of chemical (hydrolysis, saponification, oxidation, polymerization, etc.), physical (evaporation, change in consistency, delamination, enlargement of particles) and biological (souring, etc.) phenomena change their properties. To this end, various chemical (using stabilizers, antioxidants, preservatives, etc.) or physical (using nonaqueous solvents, etc.) methods are widely used to stabilize homogeneous soft drugs ${ }^{50}$.

To stabilize heterogeneous drug systems (suspensions, emulsions), thickeners and emulsifiers are used in the form of surfactants and high molecular weight compounds ${ }^{51}$. Promising for obtaining emulsion bases in the production of soft drugs are modern silicone emulsifiers Dow Corning elastomers, which have already crossed the boundary of the concept of excipients due to moisturizing, emollient and other properties ${ }^{52}$.

On the other hand, for easily soluble and adsorbable drugs, the problem of prolonging the release time and lowering peak concentrations remains a difficult task, various methods have been developed for solving which

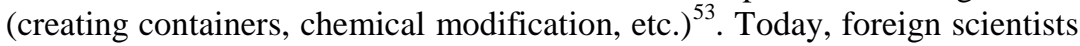
are actively using advanced technologies for creating nanoemulsions using various excipients. Using ultrasound, nanoemulsions of lauric acid are produced with an oil droplet size of about $100 \mathrm{~nm}$. A high-pressure jet technique is also used to create coconut oil nanoemulsions ${ }^{54}$.

50 Бірюкова С.В., Тарасенко В.О., Колокова А.В., Давтян Л.Л. Вивчення антимікробної активності крему та гелю на основі цефтріаксону та німесуліду Фармацевтичний часопис. 2009. № 1(9). C. 52-56. DOI 10.11603/2312-0967.2009.1

${ }^{51}$ Debjit B., Harish G., B. Pragati K.S., Duraivel K.P., Sampath K. Recept advances in novel topical drug delivery system. The Pharma Innovation. 2012. № 1 (9). P. 12-31. ISSN: 2277-7695.

Sheskey P.J., Cook W.G., Cable C. G. Handbook of pharmaceutical excipients. London : APhA/Pharmaceutical Press, 2017. ISBN 9780857112712.0857112716.

52 Kadajji V.G., Betageri G.V. Water soluble polymers for pharmaceutical Applications. Polymers. 2011. № 3(4). p. 1972-2009. DOI 10.3390/ polym3041972.

Kiamahalleh M.V., Mellati A., Madani S.A., Pendleton Ph., Zhang Hu, Hadi Madani, S.H. Smart carriers for controlled drug delivery: thermosensitive polymers embedded in ordered mesoporous carbon. Journal Pharmaceutical Science. 2017. № 106(6). DOI 10.1016/j.xphs.2017.02.010.

53 Swarbrick J. Encyclopedia of pharmaceutical science and technology. Fourth Edition, Six Volume Set Dasel Marcel Dekker, New York. 2013. ISBN 9781841848198 CAT\# H100233.

${ }^{54}$ Chauhan N.P.S., Pathak A.K., Bhanat K. Encyclopedia of biomedical polymers and polymeric biomaterials. Taylor \& Francis, New York. 2016. ISBN-13: 978-1439898796. ISBN-10: 1439898790. 
Thus, the development of physics, chemistry, biochemistry determines the rapid development in the field of pharmacy. By varying various combinations of excipients, one can control the strength and duration of the therapeutic effect of soft drugs, regulate the bioavailability of active pharmaceutical ingredients, and influence their accumulation in tissues and the elimination process.

The main tendency in the development of the production of soft dosage forms is associated with the use of increasingly effective active pharmaceutical ingredients, modern excipients and the creation on their basis of combined preparations intended for the treatment of certain diseases, given their etiology and pathogenesis.

\section{Justification for the choice of foundation for the cream}

The authors conducted studies to justify the choice of foundation for the cream. In order to substantiate the type and composition of the base, we have investigated the basics of various nature, which are most commonly used in surgical practice and are part of a combination of mild soft drugs. This takes into account the medical and biological requirements for soft medicines. In the first stage of research we introduced into the dosage form alloy PEO-400 with PEO-1500 and emulsifier 1 in certain proportions. Alloy PEO-400 with PEO-1500 exhibits high osmotic activity (300-400\%), which is undesirable for the treatment of surgical wounds, especially wounds of 2-3 phases. Although the clinical manifestations of the wound may be accompanied by some secretions, such a high dehydrating ability of the base is not desirable. This can lead to locally irritating action ${ }^{55}$.

To stabilize the model emulsion compositions of the 1st and 2nd kind, emulsifier № 1 and T2 were used at the concentrations required to form a stable emulsion of a certain kind. For the preparation of water-alcohol gels as a gelling agent used carbomer company Noveon under the trade name Carbopol brand $980 \mathrm{NF}$ at a concentration of $1 \%$. To neutralize the gel, triethanolamine $(0,65 \%)$ was applied to $\mathrm{pH} 6$.

The composition of the model bases are given in table 1 .

55 Бірюкова С.В., Тарасенко В.О., Колокова А.В., Давтян Л.Л. Вивчення антимікробної активності крему та гелю на основі цефтріаксону та німесуліду Фармацевтичний часопис. 2009. № 1(9). С. 52-56. DOI 10.11603/2312-0967.2009.1

Руденко В. В., Власенко І. О., Ващук В. А. Вивчення осмотичної активності комбінації гідрофільних неводних розчинників для моделювання препарату, дослідження осмотичної активності комбінацій гідрофільних неводних розчинників для моделювання лікарського засобу для обробки в процесі лікування ран фази I. Фармачевтичний журнал. 2013. № 1, с. 46-49. ISSN 0367-3057. 
Table 1

Model ointment base composition

\begin{tabular}{|c|c|c|c|c|c|c|c|c|c|c|c|c|c|c|}
\hline \multirow{2}{*}{$\begin{array}{c}\text { Base } \\
\text { No }\end{array}$} & \multirow{2}{*}{$\begin{array}{c}\text { Ointment } \\
\text { base type }\end{array}$} & \multicolumn{10}{|c|}{ Model samples of basics } \\
\cline { 3 - 14 } & $\mathbf{1}$ & $\mathbf{2}$ & $\mathbf{3}$ & $\mathbf{4}$ & $\mathbf{5}$ & $\mathbf{6}$ & $\mathbf{7}$ & $\mathbf{8}$ & $\mathbf{9}$ & $\mathbf{1 0}$ & $\mathbf{1 1}$ \\
\hline 1 & Vaseline oil & & 5 & & & & 10 & 20 & & & & 10 \\
\hline 2 & Glycerin & & 5 & 5 & & 5 & & 5 & & & & \\
\hline 3 & Propylene glycol & 10 & & & 17 & 45 & & & 10 & 15,5 & 15 & \\
\hline 4 & PEO-400 & 20 & 10 & 10 & 41 & 30 & 10 & 12 & 10 & 45,8 & 45 & 16 \\
\hline 5 & Carbopol 940P & 1 & 1 & 1 & & & & & 1 & & 1 & \\
\hline 6 & Triethanolamine & 0,65 & 0,65 & 0,65 & & & & & 0,6 & & 0,65 & \\
\hline 7 & Wax & & 4 & & & & & 2 & & & & 3 \\
\hline 8 & Emulsifier 1 & & & & & & 8 & 10 & 8 & 3,2 & 2 & 5 \\
\hline 9 & PEO-1500 & & & & 41 & & & 3 & 5 & 23,5 & 10 & 4 \\
\hline 10 & Vaseline & & & & & & 5 & & & & & \\
\hline 11 & Proxanol 268 & & & & & 20 & & & & & & \\
\hline 12 & $\begin{array}{c}\text { Purified water } \\
\text { up to }\end{array}$ & 100 & 100 & 100 & 100 & 100 & 100 & 100 & 100 & 100 & 100 & 100 \\
\hline
\end{tabular}

The study of the structural and mechanical properties of the samples was carried out on a viscometer with coaxial cylinders Reotest- 2 at a temperature of $20^{\circ} \mathrm{C}$. The results of rheological studies are presented in fig. 1 and 2, where the numbers of the curves correspond to the numbers of model bases in table 1 .

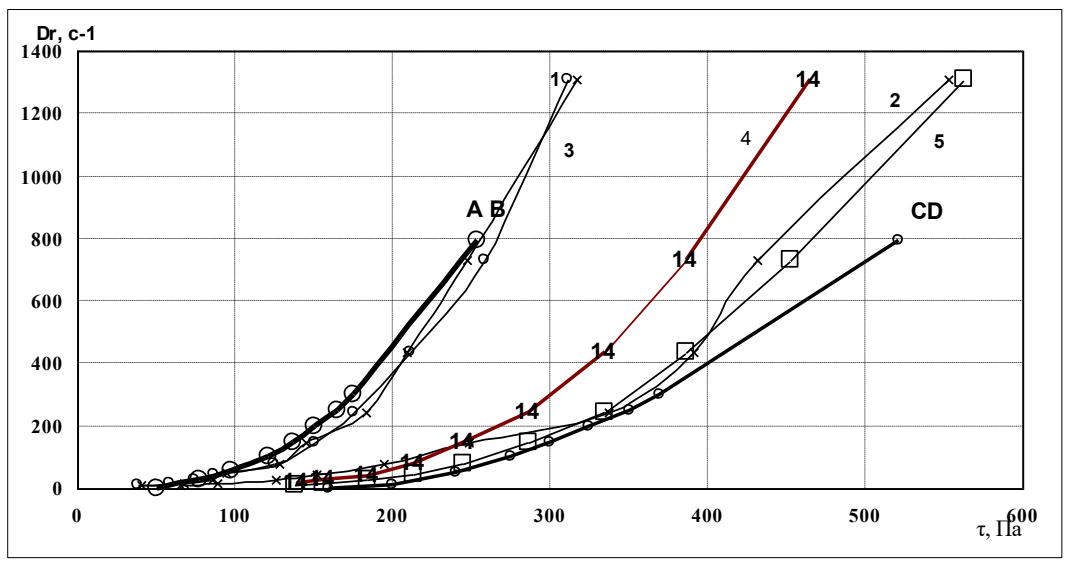

Fig. 1. Reograms of model bases $1-5$ at temperature $20^{\circ} \mathrm{C}$, $A B$ and $C D$ - limits of rheological optimum of consistency 


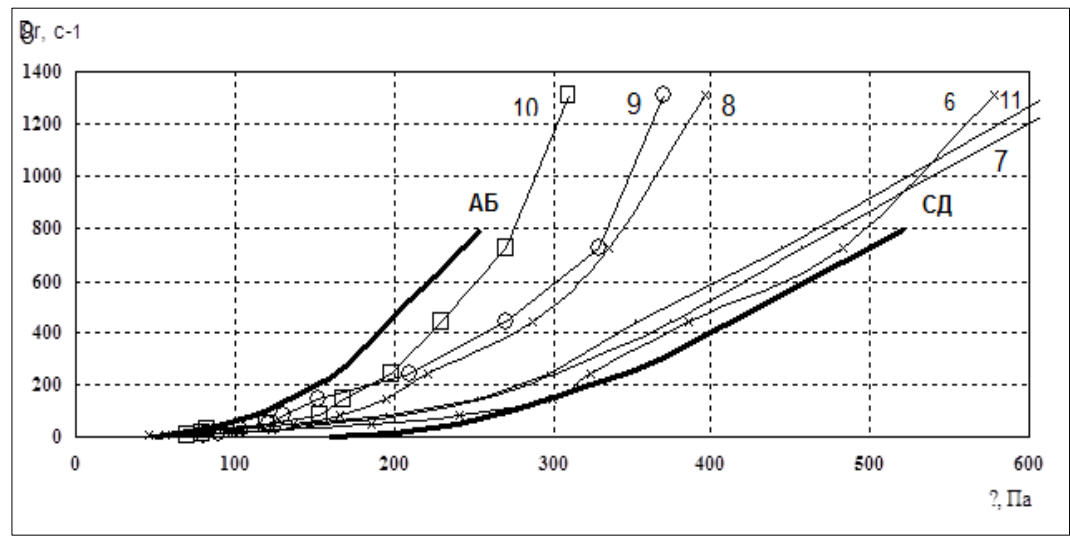

Fig. 2. Reograms of model bases 6-11 at temperature $20^{\circ} \mathrm{C} A B$ and $\mathrm{CD}$ - limits of rheological optimum of consistency

Analysis of the obtained data fig. 1 and 2 show that for all the curves there is a gradual increase in the strain rate. Then the reograms go straight, which indicates the complete destruction of the structure. The constructed curves also indicate that their fluidity begins only after some applied voltage required to break the elements of the structure. Given that the rheograms of all model samples are within the rheological optimum, we have studied their osmotic activity in order to select the optimal sample (fig. 3).

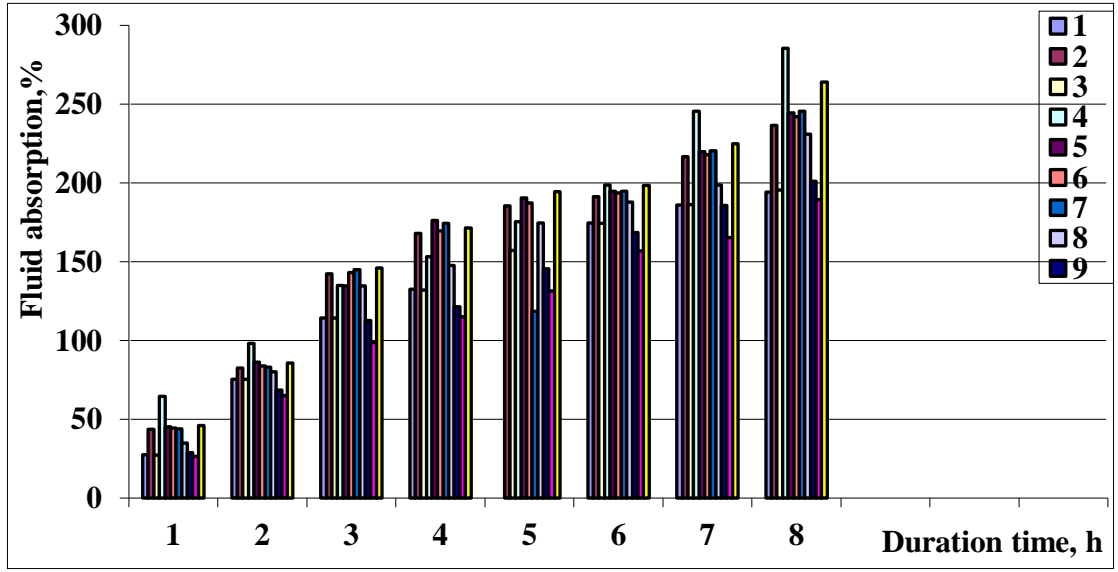

Fig. 3. Osmotic activity of model samples (numbers correspond to the numbers in table 1) 
It is proved that by osmotic activity all model samples can be arranged in the following sequence: $10<1<3<9<8<2<6<5<7<11<4$, that is, in this series high osmotic activity has sample 4 , and $10-$ smaller. Based on the medical-biological requirements for soft remedies for locally irritating action, we have selected model samples $10 ; 1 ; 3 ; 9$ with an osmotic activity of up to $207 \%$.

Thus, model sample 10 has the ability to absorb liquid at the level of $189,4 \%$, sample $1-174,4 \%$, sample $3-195,5 \%$, and $9-207,2 \%$. That is, indicators of osmotic activity differ by $10-15 \%$. While the adsorption of model 8 has a value of $230,8 \%$. Therefore, for further research, we have selected model samples $1 ; 3 ; 9$ and 10 .

The complete flow diagrams of model samples 1, 3, 9 and 10 are shown in Fig. 4.

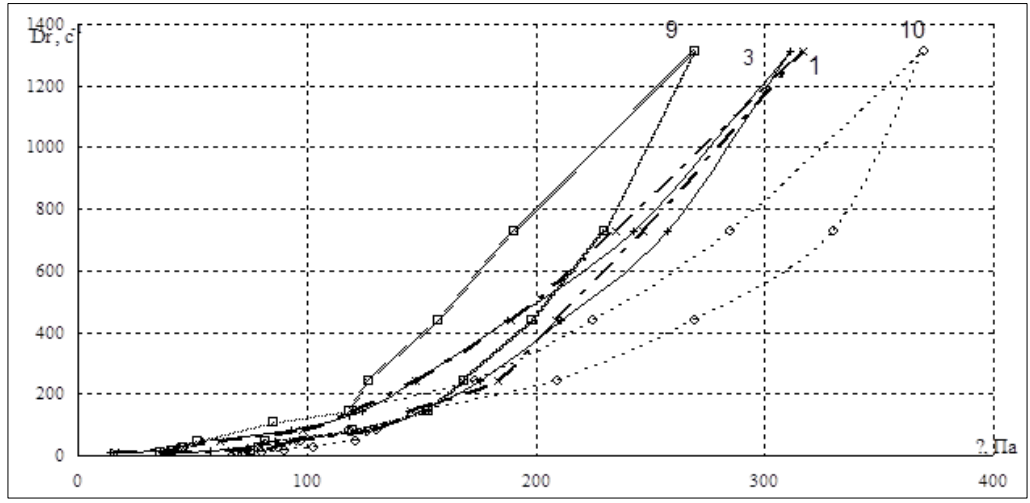

Fig. 4. Shear stress dependence of model specimens on shear rate at $20{ }^{\circ} \mathrm{C}$

From fig. 4 shows that the rheogram of the foundations are characterized by considerable nonlinearity of the mechanical behavior. The nonlinearity of the properties manifested at very low deformations, then the limit of linearity is practically unattainable in the measurement of yield stress.

The samples are plastic-viscous and thixotropic properties, due to the fact that during the period of falling voltage, the thickness of the sample is gradually recovering. Thixotropy, which describes the consumer properties of medicines, is due to the internal structure of soft formulations, which have low strength. So, from the numerical values of the yield strength depends on a qualitative assessment of consumer properties - spreadability and extrusion of tubes, which are determined by the degree of thixotropy of the system under study. 
The results of the studies all selected samples had good thixotropy, that is, appropriate consumer properties.

For a more complete and objective evaluation of consumer properties of models 1, 3, 9 and 10, namely, their spreadability, studies have been conducted to determine the offset voltage in the speed range 125-275 s- ${ }^{1}$, which is modeled namescount ointments on the skin.

The samples of the foundations were placed in a measuring cylinder viscometer, which thermostatically at a temperature of $37{ }^{\circ} \mathrm{C}$ (skin temperature) and was determined by shear stress at two shear rates 145 and $243 \mathrm{~s}^{-}$. Shear stress was calculated separately for each strain rate and the results built is limited rheogram of fluidity (fig. 5).

The results showed that I have the right to deferred 1, that $9 \in$ backfill, the fragments are mixed with reograms, the slab of which, in general of the optimum for rheology of the distinguished polygon ABVGDEKLM.

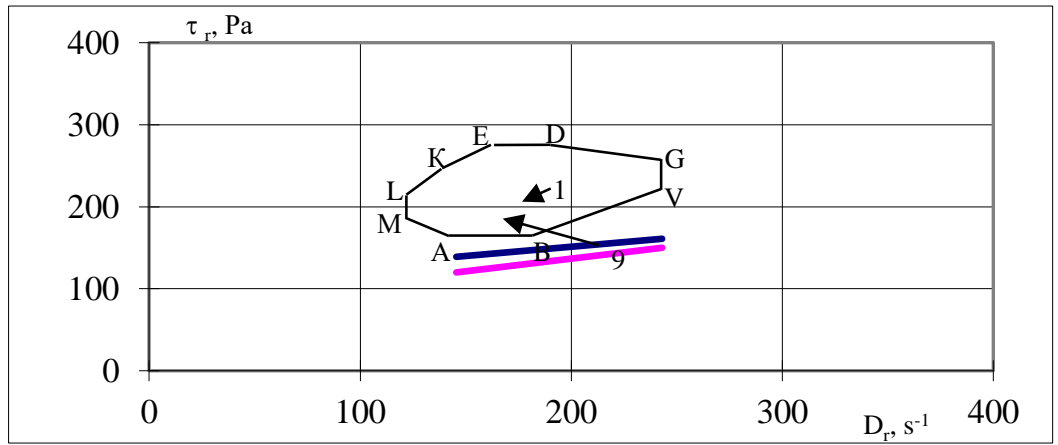

Fig. 5. Area distinguished by rheograms of effect of the ointment at $34{ }^{\circ} \mathrm{C}$ : 1 - after 2-3 s; 9 - after $15 \mathrm{~s}$

Thus, on the basis of structural and mechanical studies we have selected samples $1,3,9,10$, which are the basis for gel $-1,3$ and hydrophilic cream - samples 9 and 10. Subsequently, the selected model samples were investigated for thermo- and colloidal stability to select the optimal bases.

The thermal and colloidal stability of the model samples was performed as soon as they were made and within 1 year of storage. Studies have shown that thermo- and colloidal stability is exhibited by samples 1,3 and 9 . Sample 10, which was maintained under natural conditions for 6 months, showed heterogeneity, and after 3 months, a stratification of the system.

Due to the fact that bases 1 and 3 are different from the presence / absence of propylene glycol, glycerol and quantitative content of polyethylene oxide- 400 in the basis 1 , we will in the future conduct a study 
using the basis of model sample 1 . Therefore, in the future we will conduct research on model samples 1 and 9 .

\section{CONCLUSIONS}

Summarizing the accumulated experience in the treatment of wounds and current knowledge of biopharmaceutical aspects of the creation of soft drugs, it is concluded that successful prevention and rapid treatment of the specified pathological condition is possible with a comprehensive approach and use of common measures. Significantly increase the effectiveness of treatment of wound infection will allow the use of the basis developed by the authors for the combination cream, the composition of which is scientifically substantiated according to the pathogenesis of the wound process, taking into account its phase and nature of the microflora.

Current biopharmaceutical studies of topical medicinal products have proven that, with reasonable choice of carrier, it is possible to provide a pronounced, and sometimes enhanced, effect of the drugs introduced into its composition. Physico-chemical studies have justified the optimal carrier for ointment - PEO-1500 and PEO-400 (1: 4), whose osmotic properties ensure the elimination of purulent discharge. PEO-400, forming complexes with antimicrobial compounds, transports them to the depth of damaged tissues the main sites of microbial localization, and PEO-1500 provides a uniform and long-term absorption of exudate.

Structural-mechanical studies have proved the concentration of emulsifier No. 1 in the amount of 3,2\%.

Determination of structural and mechanical properties of the cream base indicate that it belongs to structured systems, has thixotropic properties, which causes good consumer (ease and ease of application) and technological (packing) properties.

The results of biopharmaceutical research on the development of the basis of cream for the treatment of wounds may be the basis for the development of the cream and the conduct of clinical research and introduction into industrial mass production.

\section{SUMMARY}

The publication experimentally substantiates scientific and practical approaches to the creation of modern wound healing soft medicines in the form of cream. The authors used modern methods of research: pharmacotechnological, physico-chemical and structural-mechanical - to substantiate the composition of the basis of the cream of combined action. The optimal carrier for the cream was experimentally substantiated: the emulsion base of a mixture of polyethylene oxide- 400 and polyethylene 
oxide-1500 (2: 1) and emulsifier № $1-3,2 \%$ at a constant concentration of propylene glycol $-15,5 \%$. This composition of the base involves a certain temperature regime of preparation, the order of introduction of active pharmaceutical ingredients and auxiliaries to the aqueous and oil phases, frequency and duration of mixing. Conducted rheological studies of the developed basis confirmed its compliance with the requirements. It is proved that the consistency of the developed soft drug is satisfactory, since the shear stress curves fully fit into the rheological optimum range for hydrophilic ointments. Restricted flow charts of the cream base are located in the rheological optimum zone, which confirms its satisfactory lubricity. The development and introduction into practical pharmacy of a new combination cream on a modern hydrophilic basis will significantly expand the range of medicines used for local treatment of purulent-necrotic phase of the wound process, which remains relevant for pharmaceutical technology and world medical science and practice.

\section{REFERENCES}

1. Бірюкова С.В., Тарасенко В.О., Колокова А.В., Давтян Л.Л. Вивчення антимікробної активності крему та гелю на основі цефтріаксону та німесуліду Фармацевтичний часопис. 2009. № 1(9). C. 52-56. DOI 10.11603/2312-0967.2009.1

2. Вікторов О. П., Кашуба О.В. Німесулід: оцінимо перспективи лікування [Німесулід: оцінка перспектив]. Мистецтво лікування. 2015. № 5. C. 20-22.

3. Давтян Л.Л. Технологічний спосіб введення діючих речовин до основи препарату. Військова медищина Украӥни. 2012. № 12(4), с. 61-63.

4. Давтян Л., Дроздов О., Гладышев В., Пухальская И. Фармацевтическая технология экстемпоральных лекарственных средств. $2018.700 \mathrm{c}$.

5. Давтян Л., Власенко І. Мікробіологічний скринінг - основа для створення препаратів для лікування трофічних виразок. Рецепт. 2017. № 20(1). C. 69-78.

6. Державна Фармакопея України / Державне підприємство "Український науковий фармакопейний центр якості лікарських засобів". 2-е вид. Доповнення 3. Харків : Державне підприємство "Український науковий фармакопейний центр якості лікарських засобів". 2018. 416 с. ISBN 978-966-97390-4-9.

7. Копенкін С.С., Таліцький К.А. Місцеве застосування нестероїдних протизапальних засобів у травматології та ортопедії. Вісник ортопедіï, травматології і протезування. 2013. № 1, с. 77-80.

8. Кузьмін Ю., Самсон А., Самсон М. Антибактеріальна терапія гнійних ран. Медична допомога. 2018. № 7(94). С. 13-18. 
9. Руденко В.В., Власенко І.О., Ващук В.А. Вивчення осмотичної активності комбінації гідрофільних неводних розчинників для моделювання препарату, дослідження осмотичної активності комбінацій гідрофільних неводних розчинників для моделювання лікарського засобу для обробки впроцесі лікування ран фази I. Фармацевтичний журнал. 2013. № 1, с. 46-49 ISSN 0367-3057.

10. Стефанов О.В. (ред.). Доклінічні дослідження лікарських засобів. $2001.535 \mathrm{c}$.

11. Abrantes C.G., Duarte D., Reis C.P. An overview of pharmaceutical excipients: safe or not safe. Journal Pharmaceutical Science. 2016. № 105(7). p. 2019-2026. DOI 10.1016/j.xphs.2016.03.019.

12. Alves M.P., Scarrone A.L., Santos M., Pohlmann A.R., Guterres S.S. Human skin penetration and distribution of nimesulide from hydrophilic gels containing nanocarriers. Pharmaceutical Nanotechnology. 2007. № 341 (1-2). p. 215-220. DOI 10.1016/j.ijpharm.03.031.

13. Atiyeh B.S., Dibo S.A., Hayek S.N. Wound cleansing, topical antiseptics and wound healing. International Wound Journal. 2009. № 6(6). P. 420-430. DOI 10.1111/j.1742-481X.2009. 00639.x.

14. Barajas-Nava L.A., López-Alcalde J., Roqué i Figuls M., Solà, I., Bonfill Cosp X. Antibiotic prophylaxis for preventing burn wound infection. Cochrane Database of Systematic Reviews. 2013. №6. DOI 10.1002/14651858. CD008738. pub2.

15. Cardinal M.M., Eisenbud D.E., Armstrong D.G. Serial surgical debridement: a retrospective study on clinical outcomes in chronic lower extremity wounds. Wound Repair and Regeneration. 2009. № 17(3). P. 306311. DOI 10.1111/ j.1524-475X.2009.00485. x.

16. Chan B.A., Sunting X.Li.A., Simpson J.M., Sternhagen G.L., Yu T., Darvish O.A., Naisheng J., Donghui Z. Polypeptid polymers: synthesis, characterization, and properties. Biopolymers. 2017. DOI 10.1002/bip.23070.

17. Chauhan N.P.S., Pathak A.K., Bhanat K. Encyclopedia of biomedical polymers and polymeric biomaterials. Taylor \& Francis, New York. 2016. ISBN-13: 978-1439898796. ISBN-10: 1439898790.

18. Debjit B., Harish G., B. Pragati K.S., Duraivel K.P., Sampath K. Recept advances in novel topical drug delivery system. The Pharma Innovation. 2012. № 1 (9). p. 12-31. ISSN: 2277-7695.

19. Dohmen P.M. Antibiotic resistanse in common pathogens reinforces the need to minimize surgical site infections. Journal of Hospital Infection. 2008. № 70(2). p. 15-20. DOI 10.1016/S0195-6701(08)60019-5.

20. Farooq U., Rishabh M., Bansal V., Pragati K.S. Characterization of some polymers as pharmaceutical excipient. Advances in Biological Research. 2014. № 8 (3). p. 123-126. DOI 10.5829/idosi.abr.2014.8.3.83200. 
21. Gullapalli R. P. Soft gelatin capsules (softgels). Journal Pharmaceutical Science. 2010. № 99(10). p. 47-48. DOI 10.1002/jps.22151.

22. Haag R., Kratz F. Polymer therapeutics: concepts and applications. 2006. № 45(8). p. 1198-1215. DOI 10.1002/anie.200502113.

23. Healy B.M., Freedman A.M. ABC of wound healing Infections. British Medical Journal. 2010. № 332. P. 838-841. DOI 10.1136/bmj.332.7545.838.

24. Hotz B.V., Visekruna A.A., Buhr H.J., Hotz H.G. Beyond epithelial to mesenchymal transition: a novel role for the transcription factor snail in inflammation and wound healing. World Journal of Gastrointestinal Surgery. 2010. № 14(2). P. 388-397. DOI 10.1007/s11605-009-1068-3.

25. Isaas V. L. B., Galdorfini Chiari-Andreo B., Marto J.M., Moraes J.D.D., Leone B.A., Correa M.A., Ribeiro H.M. Rheology as a tool to predict the release of alfa-lipoic acid from emulsions used for the prevention of skin aging. Hindawi Publishining International. 2015. P. 8-16. DOI 10.1155/2015/818656.

26. Islam M.T., Rodríguez-Hornedo N.P., Ciotti S.E. Rheological characterization of topical carbomer gels neutralized to different $\mathrm{pH}$. Journal Pharmaceutical Research. 2014. № 7(21), p. 1192-1199. DOI 21:1192-1199.

27. Janis J. E., Harrison B. Wound healing: part I. Basic science. Plastic and Reconstructuctive Surgery. 2016. № 138(3). P. 9-17. DOI 10.1097/PRS.0000000000002773.

28. Kadajji V.G., Betageri G.V. Water soluble polymers for pharmaceutical Applications. Polymers. 2011. № 3(4). P. 1972-2009. DOI 10.3390/ polym3041972.

29. Kiamahalleh M.V., Mellati A., Madani S.A., Pendleton Ph., Zhang Hu, Hadi Madani, S.H. Smart carriers for controlled drug delivery: thermosensitive polymers embedded in ordered mesoporous carbon. Journal Pharmaceutical Science. 2017. № 106(6). DOI 10.1016/j.xphs.2017.02.010.

30. Lindley L.E., Stojadinovic O., Pastar I., Tomic-Canic M. Biology and biomarkers for wound healing. Plastic and Reconstructive Surgery. 2016. № 138(3). p. 18-28. DOI 10.1097/PRS.0000000000002682.

31. Maisch T. Anti-microbial photodynamic therapy: useful in the future. Lasers in Medical Science. 2007. 22(2). P. 83-91. DOI 10.1007/s10103-0060409-7.

32. Maitz M.F. Applications of synthetic polymers in clinical medicine. Biosurface and Biotribology. 2015. № 1(3). DOI 10.1016/j.bsbt.2015.08.002.

33. Mastropietro D.J., Nimroozi R., Omidian H. Rheology in parmaceutical formulations - A perspective. Journal of Developing Drugs. 2013. № 2(108) DOI 10.4172/2329-6631.1000108.

34. Merkle H.P. Drug delivery's quest for polymers: where are the frontiers? European Journal Pharmaceutical Biopharmaceutic. 2015. № 97. P. 293-303. DOI 10.1016/j.ejpb.2015.04.038. 
35. Nishio N. S., Suzuki I.H. Antibodies to wounded tissue enhance cutaneous wound healing. Immunology. 2009. № 128 (3). p. 369-380. DOI. 10.1111/j.1365-2567.2009. 03119.x.

36. Owens C.D., Stoessel K.P. Surgical site infections: epidemiology, microbiology and prevention. Journal of Hospital Infection. 2008. № 70(2). p. 3-10. DOI 10.1016/S0195-6701(08)60017-1.

37. Puoci F., Piangiolino C., Givigliano F., Parisi O.I., Cassano R., Trombino S., Curcio M., Iemma F., Cirillo G., Spizzirri U.G., Restuccia D., Muzzalupo R., Picci, N. Ciprofloxacin-collagen conjugate in the wound healing treatment. Journal of Functional Biomaterials. 2012. № 3. P. 361-371. DOI 10.3390/ jfb3020361.

38. Rüttermann M., MaierHasselmann A., Nink-Grebe B., Burckhardt M. Local treatment of chronic wounds. Deutsches Ärzteblatt International. 2013. № 110(3). P. 25-31. DOI 10.3238/arztebl.2013.0025.

39. Sheskey P.J., Cook W.G., Cable C. G. Handbook of pharmaceutical excipients. London: APhA/Pharmaceutical Press, 2017. ISBN 9780857112712.0857112716.

40. Swarbrick J. Encyclopedia of pharmaceutical science and technology. Fourth Edition, Six Volume Set Dasel Marcel Dekker, New York. 2013. ISBN $9781841848198-C A T \#$ H100233.

41. Trostrup H., Bjarnsholt T., Kirketerp-Moller K., Hoiby N., Moser C. What is new in the understanding of non-healing wounds epidemiology, pathophysiology and therapies. Hundawi Publishing Corporation. 2013. (ID 625934). DOI 10.1155/2013/625934.

42. Vyas K.S., Vasconez, H.C. Wound healing: biologics, skin substitutes, biomembranes and scaffolds. Healthcare. 2014. № 2(3). P. 356-400. DOI 10.3390/ healthcare 2030356.

\section{Information about authors:}

Tarasenko V. O.,

Candidate of Pharmaceutical Sciences, Associate Professor of Military Pharmacy Department

Ukrainian Military Medical Academy 45/1, Moskovskay str., Kyiv, 01015, Ukraine

Pidlisniy O. V., PhD Student of Military Pharmacy Department Ukrainian Military Medical Academy 45/1, Moskovskay str., Kyiv, 01015, Ukraine 